\title{
Diet enrichment and the reproductive season of captive Sunda Porcupine (Hystrix javanica F. Cuvier 1823)
}

\author{
Nurul Inayah ${ }^{1, *}$, Andri Permata Sari ${ }^{1}$, Wartika Rosa Farida ${ }^{1}$, Herjuno Ari Nugroho ${ }^{1}$, Tri Hadi Handayani ${ }^{1}, R$. \\ Lia Rahadian Amalia ${ }^{1}$, and Fajrin Shidiq ${ }^{1}$ \\ ${ }^{1}$ Museum Zoologicum Bogoriense, Division of Zoology, Research Center of Biology, Indonesian Institute of Sciences, 16911 \\ West Java, Indonesia
}

\begin{abstract}
This study aimed to extend our current knowledge of Sunda porcupine reproductive biology with emphasis on environmental enrichment and the reproductive season. Tomato and bean sprout feeding able to increase sperm quantity, sperm motility, and viability, as well as increase FSH and estrogen hormone levels. Four pairs of captive Sunda porcupine were used. Two pairs (fed with fresh tomato and bean sprout, enrichment group) and two pairs as control. The birth rate of enrichment group higher (with twin litter per year) than that in control (only one litter per year). It indicated that tomato and bean sprout feeding affect the birth rate in Sunda porcupine. The recent study showed that captive Sunda porcupine births occurred throughout the year, with no more than 1-2 litter per year and are have no interbirth-interval. The birth peak of captive Sunda porcupine occurs between April to August. Biparental activities during birth occurred. However, the female spent $50 \%$ of the time with the newborn. There was no courtship behaviour throughout the first two or three months of life of the cub.
\end{abstract}

\section{Introduction}

Sunda porcupine (Hystrix javanica) is one of the members of famili Hystricidae distributed in Java Island, Lombok, Madura, Flores, and Tanah Jampea islands of Indonesia [1]. Moreover, found in sea level to $1500 \mathrm{~m}$ [2]. H. javanica has a current IUCN status of 'Least Concern' [3]. And since 2018, H. javanica also protected in Indonesia. In many Indonesian regions, wildlife represents a significant source of food and financial resource for rural and urban populations. People hunt the porcupine for meat consumption caused a high demand for porcupine. The high rate of exploitation will reduce the population, which in turn increases its value and leads to its extinction in the wild [4]. However, Sunda porcupine has potential as mini livestock, which is particularly true in areas with large portions of rainforest where the raising of livestock is difficult, and traditional hunting remains the primary way of obtaining animal protein [5].

Although their apparent reproductive success in the wild, captive breeding of this species has until recently been remarkably sparse recently, captive breeding is a standard tool used for maintaining biodiversity and preserving demographically stable and genetically healthy populations [6]. One of the putative aims of captive breeding is to preserve in captivity populations of animals as representatives of their wild ancestors, for posterity, research, and education. Once the animal being captivated, it is necessary to provide environmental enrichment. Environmental enrichment is a method for improving the well-being of animals in captivity, and it can have profoundly beneficial effects on their behaviour and physiology [7]. Correctly, enrichment techniques used to optimize the levels of social and physical stimulation provided by captive environments to maximize reproduction and ensure healthy behavioural development.

Successful captive breeding programs also require monitoring of the reproductive status of the target animals [8, 9]. Data collection on the reproductive biology of Sunda porcupines is challenging. Notably, in the wild, as they are burrow-living, elusive, shrub wooddwelling, and nocturnal animals. Indeed, some information is available for Malayan porcupine Hystrix brachyura [10], and Himalayan porcupine Hystrix hodgsoni [11]. Mating behaviour and maternal care of H. brachyura in captivity reported by Farida et al. [12] while there is no information and report on the reproductive season of $H$. javanica both in the wild and captivity. So only observations on the breeding season of captive individuals are available for $H$. javanica. Several reproductive events occur in winter, an unusual biological feature for a rodent from a temperate country

\footnotetext{
* Corresponding author: nurulinayah.as@gmail.com
} 
[13]. However, in a tropical country, the reproductive events in captive porcupine usually occur in the late summer and the early rainy season. The estrus cycle of the most members of the genus Hystrix is 28 to 36 days and the gestation period of 100 to 110 days. In Hystrix sumatrae, breeding generally occurs once a year from December through March. The litter comprises one or two precocial in the late summer (November through December) [14], while the reproductive season of a captive Sunda porcupine is still unknown.

Enrichment for porcupine in captive facilities includes housing and diet. To increase the reproductive rate, we use tomato and bean sprout feeding as diet enrichment during the study. Tomato provides a high concentration of lycopene. According to Agrawal [15], reported that dietary intake of lycopene improves semen quality. Moreover, lycopene daily administration of an appropriate dose of lycopene can significantly increase sperm quantity, sperm motility, and viability. Lycopene given to intoxicated rats was able to reduce testicular damage $[16,17]$. Likewise, mung bean sprouts able to increase the percentage of morphology and motility of spermatozoa [18]. According to Fatmaningrum and Ningtyas [19] described that the administration of mungbean sprout extract caused an increase in FSH and estrogen hormone levels of white rats (Rattus norvegicus). So, this study aimed to extend our current knowledge of $H$. javanica reproductive rate with emphasis on environmental enrichment (tomato and bean sprout feeding) and the reproductive season.

\section{Material and Method}

Four pairs [four females and four females, two years old] of Sunda porcupine with an average weight is $6-8 \mathrm{~kg}$ from the captive population at Research Center for Biology-Indonesian Institute of Sciences used for this study. The data for the study collected through direct observation in a year from January - December 2018.

Table 1. Diet fed to Sunda porcupine

\begin{tabular}{|lr|lr|}
\hline \multicolumn{2}{|c|}{ Control (C) } & \multicolumn{2}{c|}{ Diet enrichment (E) } \\
\hline Ingredients & & Ingredients & $100 \mathrm{~g}$ \\
\hline Sweet potatoes & $100 \mathrm{~g}$ & Sweet potatoes & $100 \mathrm{~g}$ \\
Corn & $100 \mathrm{~g}$ & Corn & $100 \mathrm{~g}$ \\
Guava & $100 \mathrm{~g}$ & Guava & $100 \mathrm{~g}$ \\
Kale & $150 \mathrm{~g}$ & Kale & $100 \mathrm{~g}$ \\
Papaya & $100 \mathrm{~g}$ & Papaya & $50 \mathrm{~g}$ \\
Coconut & $50 \mathrm{~g}$ & Coconut & $20 \mathrm{~g}$ \\
Vitamin B complex & $20 \mathrm{~g}$ & Vitamin B complex & $20 \mathrm{~g}$ \\
Calcium powder & $20 \mathrm{~g}$ & Calcium powder & $150 \mathrm{~g}$ \\
& $640 \mathrm{~g}$ & Tomato & $\underline{100 \mathrm{~g}}$ \\
& & Bean sprout & $840 \mathrm{~g}$ \\
\hline
\end{tabular}

Breeding pairs housed in five enclosures, each side separated by an aisle. All enclosures are uniform in size and shape $(3.9 \mathrm{~m} \times 2.25 \mathrm{~m})$; a $2.6 \mathrm{~m}$-high brick wall surrounded the enclosures and ram wire netting extended above the wall to prevent entry by scavenging birds. The roof ran down the whole of the enclosure covering each enclosure, and the floor of all enclosures was soil.

Four of the breeding pairs housed in enclosures and maintained on vegetables and fruits-based diet [12]. Two pairs of enrichment diet (E) groups and two pairs of control groups feed at 4 p.m. (C) (Table 1). The nutritional value of the feed analysed with proximate, then the feed intake calculated. To extend our knowledge about the birth season, parental care behaviour recorded and analysed descriptively.

\section{Result and Discussion}

The nutrient composition of the diet treatment demonstrated in Table 2 and Table 3 based on dry weight as consumed. The fresh consumption of coconut, corn, papaya, sweet potato was similar in two groups. However, the feed intake of both guava and kale was higher in the enrichment groups, in comparison to the control groups (Figure 1). It indicates that feed intake differences could be influenced by palatability and appetite of porcupines. Palatability is defined as the sensory stimulation of appetite. The increased intake is the evidence for the difference in palatability and the effect of palatability on intake [20]. The feed intake in enrichment groups influenced by tomato feeding. Tomato is one of the fruits which has high acceptability and palatability, and it can be fed ad libitum to the livestock [21].

Nutrition plays a crucial role in the maintenance of animal reproductive performance. Dietary nutrient balance has been shown to strongly influence many lifehistory traits of animals, including growth, reproduction, and lifespan [22]. In this study, the total protein content in the two groups porcupine feed is $10 \%$ of the total feed. Protein requirement for animals is $10-15 \%$ of total feed [23]. Protein supplementation support high production [24]. Regulation of maternal dietary protein intake during gestation is essential for proper embryonic survival, growth, and development [25]. Low maternal dietary protein intake impacts fetal body composition, body weight, metabolism, and hormonal balances [26]. Also affecting the immune system, low maternal dietary protein intake ( $4 \%$ crude protein) reduced concentrations of protein, albumin, and gamma-globulin in plasma of neonatal rat pups compared to pups from a control fed dam (10\% crude protein) [27]. However, a high protein intake $(>17 \%)$ in cow has no effects or not significant on the reproductive performance of the animal [28, 29], in the cow [30], in the monkey, was not significantly affected sperm quality as well [31].

Two porcupine pairs with the diet enrichment had a higher birth rate than that in control groups (Figure 1). The diet enrichment groups were once birth with twin litters per year, compared to the control group only consisted of one litter. Tomato feeding in the enrichment group indicates an impact on reproduction. Tomato has nutrient such as protein, vitamin $\mathrm{A}, \mathrm{E}$, and $\mathrm{C}$, folate, lycopene, carotenoid, riboflavin, lutein, and potassium (Table 3). The essential compound in the carotenoid 
Table 2. Nutrient composition of the feed given to porcupine

\begin{tabular}{lccccc}
\hline Sample & $\begin{array}{c}\text { Ash } \\
(\%)\end{array}$ & $\begin{array}{c}\text { Protein } \\
(\%)\end{array}$ & $\begin{array}{c}\text { Fat } \\
(\%)\end{array}$ & $\begin{array}{c}\text { Fibre } \\
(\%)\end{array}$ & $\begin{array}{c}\text { Energy } \\
(\mathrm{Cal} / \mathrm{g})\end{array}$ \\
\hline Corn & 3,80 & 16,56 & 2,52 & 8,82 & 68,31 \\
Sweet potato & 3,56 & 3,50 & 0,89 & 15,90 & 76,15 \\
Guava & 0,55 & 0,82 & 0,20 & 2,29 & 96,14 \\
Papaya & 3,73 & 4,76 & 0,71 & 5,17 & 85,63 \\
Kale & 11,70 & 33,63 & 0,44 & 1,10 & 53,13 \\
Coconut & 2,73 & 3,57 & 32,18 & 11,75 & 49,77 \\
Tomato & 8,34 & 14,75 & 1,38 & 13,97 & 61,56 \\
Bean sprout & 5,52 & 3,91 & 0,41 & 19,60 & 70,56 \\
\hline Enrichment groups (E) & $39,93 \pm 3,51$ & $81,5 \pm 11,05$ & $38,73 \pm 11,07$ & $78,6 \pm 6,64$ & $561,25 \pm 15,73$ \\
Control (C) & $26,07 \pm 3,80$ & $62,84 \pm 12,61$ & $36,94 \pm 12,77$ & $45,03 \pm 5,72$ & $429,13 \pm 18,15$ \\
\hline
\end{tabular}

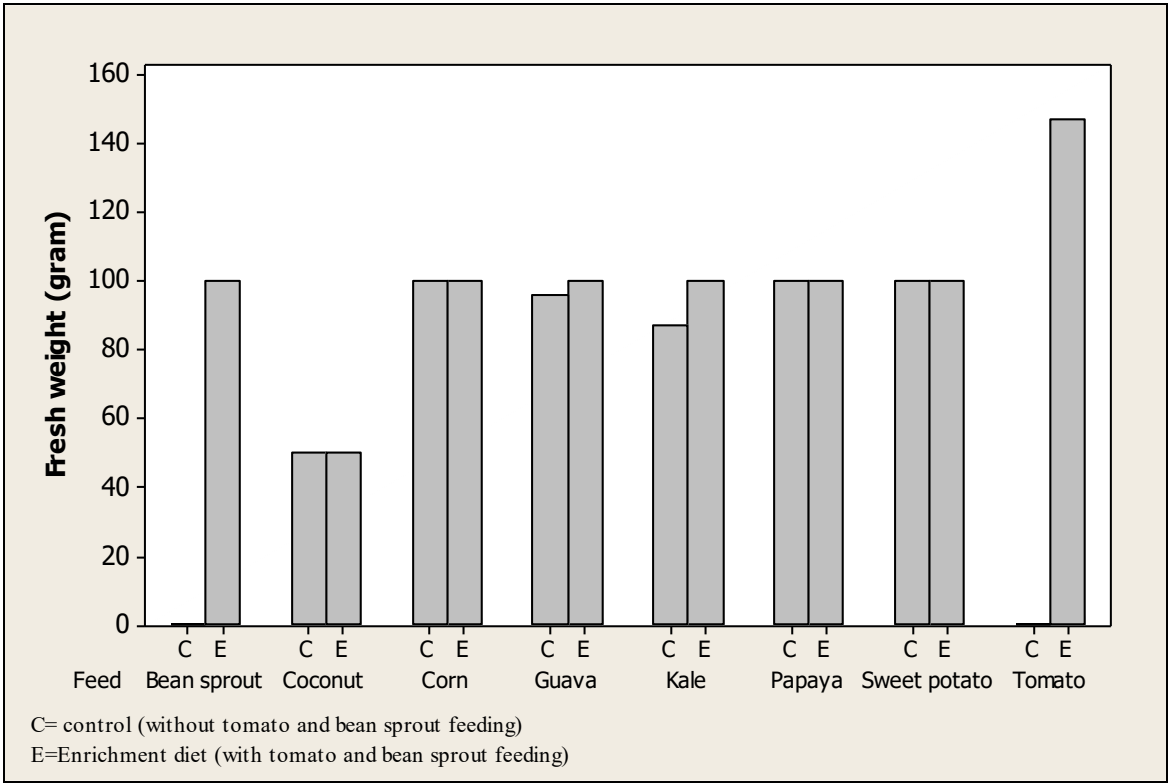

Fig. 1. Sunda porcupine feed intake of fresh feed

family is lycopene. Lycopene, a carotenoid, has a strong antioxidant effect and is beneficial in restoring a balance between reactive oxygen radicals $[32,33]$. The previous research showed that lycopene concentrated in the testes than any part of the body. It might relate to the antioxidative role in spermatogenesis [34]. A study shows that lycopene in tomato has the potential for impairment testicular function in adult male SpragueDawley rats, able to restore body weight, serum testosterone [35] and prevent DNA damage [32, 36]. Tomato feeding and lycopene administration daily improve semen viability [37]. It also improves semen production, fertility, immunity, sperm motility in broilers [38]. It indicates that lycopene plays a role in maintaining sperm integrity $[38,39]$.

The previous research described that that lycopene provides the continuations of follicular growth, and improving cytoplasmic maturation of porcine oocytes by increasing connexin-43 expression in the ovary [40]. On the other hand, according to Yildiz and Snadikci [32], the administration of lycopene increased connexin-43 expression the primordial, secondary and large antral follicles in the rat ovaries. The finding support that tomato feeding might influence the maturity of follicles in the female Sunda porcupine.

Besides tomato, mung bean sprout fed to the porcupines (enrichment diet). Mung bean sprout contains protein, ascorbic acid, fat, riboflavin, iron, zinc, fibre, calcium, and niacin (Table 3), tocopherol and vitamin E, and some minerals (selenium, manganese, and copper) [41]. In this study, bean sprout feeding might improve sperm morphology and motility. The quality of spermatozoa is one of the factors that affect reproduction. Abnormalities in the sperm head shape will make it difficult to penetrate the cell wall of the egg, while the spermatozoa have abnormalities in the tail will be challenging to reach the egg or ovum. It will be at higher risk of experiencing failure in fertilization [18]. The previous study reported that bean sprouts extract at a dose of $100 \mathrm{mg} / 20 \mathrm{~g}$ affected the recovery of protein profiles in mice spermatozoa [41], improve sperm quality including number, shape (morphology), motility, and viability [18]. As tomato, the use of 2-3 g bean sprout in the feed increased sperm quality, especially in the case of motility and sperm viability in ettawah goat [42]. 
Table 3. Nutritional content per $100 \mathrm{~g}$ of bean sprout $[65]^{1},[66]^{2}$, and $[61]^{3}$ and nutritional content per $100 \mathrm{~g}$ of Tomato $[67]^{4},[60]^{5}$, $[63]^{6}$, and [68].

\begin{tabular}{|c|c|c|c|c|c|c|c|c|c|c|c|c|}
\hline Sample & $\begin{array}{l}\text { Energy } \\
\text { (Cal.) }\end{array}$ & $\begin{array}{l}\text { Water } \\
(\%)\end{array}$ & $\begin{array}{l}\text { Ash } \\
(\%)\end{array}$ & $\begin{array}{l}\text { Protein } \\
(\%)\end{array}$ & $\begin{array}{l}\text { Ascorbic } \\
\text { Acid (mg) }\end{array}$ & $\begin{array}{l}\text { Fat } \\
(\mathrm{g})\end{array}$ & $\begin{array}{l}\text { Riboflavin } \\
\text { (mg) }\end{array}$ & $\begin{array}{l}\text { Iron } \\
\text { (mg) }\end{array}$ & $\begin{array}{l}\text { Zinc } \\
(\mathrm{mg})\end{array}$ & $\begin{array}{l}\text { Fibre } \\
\text { (g) }\end{array}$ & $\begin{array}{l}\text { Calcium } \\
(\mathrm{mg})\end{array}$ & $\begin{array}{l}\text { Niacin } \\
(\mathrm{mg})\end{array}$ \\
\hline \multirow{4}{*}{$\begin{array}{l}\text { Mung } \\
\text { Bean } \\
\text { sprout }\end{array}$} & $397^{2}$ & $83,3^{2}$ & $4,55^{2}$ & $37,3^{2}$ & \multirow{3}{*}{$130,7^{2}$} & & $0,85^{2}$ & $9.58^{2}$ & $4,62^{2}$ & & \multirow{3}{*}{$83^{1}$} & \multirow{3}{*}{$1,8^{1}$} \\
\hline & $334^{1}$ & $10,1^{1}$ & $3,4^{1}$ & $22,9^{1}$ & & $1,4^{1}$ & \multirow[t]{2}{*}{$0.47^{1}$} & $11,26^{1}$ & $3,8^{1}$ & $1,4^{1}$ & & \\
\hline & $15,74^{3}$ & & $43 g^{3}$ & $\begin{array}{l}170^{3} \\
13,6^{7}\end{array}$ & & $0,2^{3}$ & & & & $\begin{array}{l}19.0^{3} \\
49^{7}\end{array}$ & & \\
\hline & $\begin{array}{r}\text { Vitamin } \\
\text { (IU } / \mathrm{mg})\end{array}$ & $\begin{array}{r}\text { Vit } \\
\text { (II }\end{array}$ & $\begin{array}{l}\min E \\
/ / \mathrm{mg})\end{array}$ & $\begin{array}{c}\text { Vitamin C } \\
\text { (IU/mg) }\end{array}$ & $\begin{array}{c}\text { Folate } \\
(\mu \mathrm{g})\end{array}$ & \multicolumn{2}{|c|}{$\begin{array}{l}\text { Phenolic } \\
\text { compound }\end{array}$} & pene & $\beta$-Carotene & \multicolumn{2}{|c|}{$\begin{array}{c}\text { Lutein } \\
(\mu \mathrm{g})\end{array}$} & $\begin{array}{l}\text { Potassium } \\
\text { (mg) }\end{array}$ \\
\hline Tomato & $743^{5}$ & $0.1^{1}$ & $-0.62^{4}$ & $8-94,9^{4,5}$ & $31.5^{4,5}$ & \multicolumn{2}{|c|}{$3.5-5.5^{4}$} & $23.6^{4}$ & $\begin{array}{l}0.28-1^{4} \\
8,83-86,24^{6}\end{array}$ & \multicolumn{2}{|c|}{$32-800^{4}$} & $279^{5}-2304^{6}$ \\
\hline
\end{tabular}

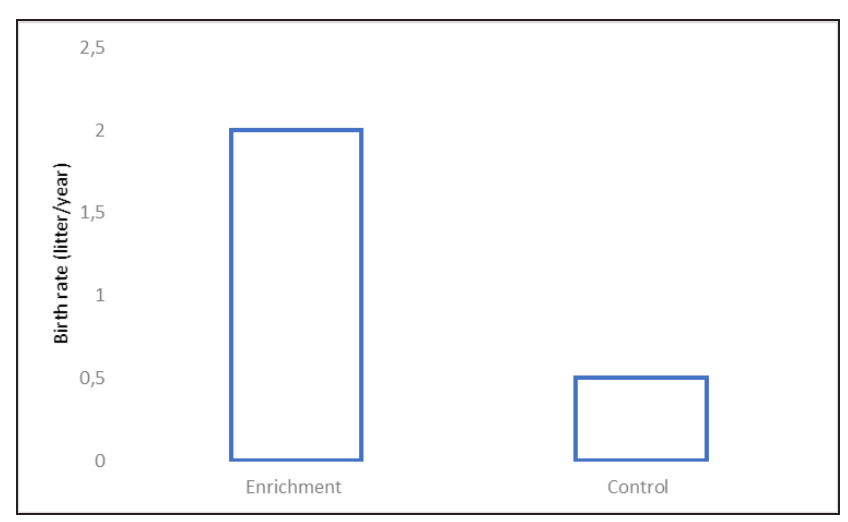

Fig. 2. The reproduction rate of Sunda porcupine

Bean sprout is one of the phytoestrogens dietary that have significant consequences for the reproductive health of a wide range of mammals. Bean sprout in proprietary feeds for rodent was found sufficient to stimulate the uterus in rat and mice [43, 44]. Fatmaningrum and Ningtyas [45] stated that it might influence the level of FSH and estrogen hormone. Vitamin $\mathrm{E}$ and vitamin $\mathrm{C}$ contained in bean sprout extract act as antioxidants which suppress the effects of free radicals. Rohmawati [46] also found that the administration of Vitamin $\mathrm{C}$ and $\mathrm{E}$ combination increased FSH levels in rats through the improvement of oxidative stress. A study shows that vitamin E therapy during the preovulatory period can prevent excessive reactive oxygen species (ROS) production and increase multiple births in goats $[47,48]$. Dietary protein intake is a crucial determinant in embryonic survival, growth, and development. A study shows that bean sprout contains the amino acid, Arginine (Table 4). Herring et al. [25] reported that dietary supplementation of Arginine during gestation has been effective in improving embryonic survival and development of the conceptus in many species, including humans, pigs, sheep, mice, and rats. It indicated that bean sprout and tomato combination feeding to the porcupines might increase the FSH, stimulate follicle formation, and increased embryonic survival. It might result in the twin birth in Sunda porcupine. However, we need further study about oestrous and hormonal changes in porcupine to ensure the effectiveness of the feeding.
Sunda porcupines often found in Java, but no reproductive data available. The reproductive record of Malayan porcupine (H. brachyura) and Sumatran porcupine (Hystrix sumatrae) is available in some literature. However, birth period peak and the average weight of the offspring and interbirth-interval on Sumatran porcupine (H. sumatrae) is unknown. Reproductive biology of Hystricidae demonstrated in Table 5. The present study showed that captive Sunda porcupine births occurred throughout the year, with no more than 1-2 litter per year. It supports the previous study that porcupine may breed throughout the year in captivity, with constant food supply $[11,49,50]$. Sunda porcupine in captivity has no interbirth-interval, and the reproduction peak of Sunda porcupine occurs between April to August, as dry season in Indonesia.

Table 4. Free amino acids contained in fresh bean sprout [76].

\begin{tabular}{lr}
\hline Amino acid & $(\mathrm{mg} / 100 \mathrm{~g})$ \\
\hline Lysin & 5,7 \\
Histidine & 1,9 \\
Ammonia & 17,0 \\
Arginine & 9,4 \\
Aspartic acid & 13,2 \\
Threonine & 9,4 \\
Serine & 11,3 \\
Glutamic acid & 13,2 \\
Proline & 5,7 \\
Glycine & 1,9 \\
Alanine & 5,7 \\
Methionine & 1,3 \\
Valine & 13,2 \\
Isoleucine & 9,4 \\
Leucine & 7,5 \\
Tyrosine & 3,8 \\
Phenylalanine & 5,7 \\
tryptophan & 0,5 \\
\hline
\end{tabular}

In captivity, the young Sunda porcupine reaches sexual maturity in nine months up to two years. The gestation period is around 100-113 days, and weaning period 2,5-3 months. Van Aarde and Van Wyk [50] reported that reproduction in sexually mature females does not occur until their dismissal. At birth, the litter has short and soft quills. The quills harden within a few hours after birth, and it begins to eat solid food around 14 days old but continues nursing for up to 12 weeks. The bodyweight of Sunda porcupine cub in two days 
Table 5. Information on the reproductive biology of Hystricidae. $[11]^{1} ;[69]^{2} ;[50]^{3} ;[58]^{4} ;[70]^{5} ;[71]^{6} ;[72]^{7} ;[57]^{8} ;[73]^{9} ;[59]^{10}$; $[13]^{11} ;[74]^{12} ;[14]^{13}$, and $[75]^{14}$.

\begin{tabular}{|c|c|c|c|c|c|c|c|}
\hline & Species & $\begin{array}{l}\text { *Hystrix } \\
\text { javanica }\end{array}$ & $\begin{array}{l}\text { Hystrix } \\
\text { brachyura }\end{array}$ & $\begin{array}{l}\text { Hystrix } \\
\text { sumatrae }\end{array}$ & $\begin{array}{l}\text { Hystrix } \\
\text { africaaustralis }\end{array}$ & $\begin{array}{c}\text { Hystrix } \\
\text { indica }\end{array}$ & $\begin{array}{l}\text { Hystrix } \\
\text { cristata }\end{array}$ \\
\hline \multirow{2}{*}{$\begin{array}{l}\text { Sexual } \\
\text { maturity }\end{array}$} & Male & 9-12 months & ND & \multirow{2}{*}{$\begin{array}{c}9 \text { months - } \\
2 \text { years }{ }^{13}\end{array}$} & 8-18 months ${ }^{2,4}$ & 7 months ${ }^{9}$ & 8-18 months ${ }^{2,10}$ \\
\hline & Female & 12 months & 12 months $^{1,2}$ & & $12-14$ months $^{2,4}$ & 9 months $^{9}$ & $9-16$ months $^{2,10}$ \\
\hline \multicolumn{2}{|c|}{ Gestation period } & 100-112 days & $\begin{array}{l}\text { 100-110 } \\
\text { days } 1,2,14\end{array}$ & $\begin{array}{l}\text { 93-110 } \\
\text { days }^{12}\end{array}$ & 94 days $^{5}$ & $90-112$ days $^{6}$ & $90-120$ days $^{2,11}$ \\
\hline \multicolumn{2}{|c|}{ Birth period peak } & $\begin{array}{l}\text { April to } \\
\text { August }\end{array}$ & ND & ND & $\begin{array}{l}\text { August \& } \\
\text { March }^{6}\end{array}$ & $\begin{array}{l}\text { March \& } \\
\text { September }\end{array}$ & ND \\
\hline \multirow[t]{3}{*}{ Litter size } & $1 \mathrm{cub}$ & $60 \%$ & & 1 or $2 \mathrm{cub}^{12}$ & $58.8 \% 0^{5}$ & $33.3 \%{ }^{9}$ & ND \\
\hline & $2 \mathrm{cub}$ & $40 \%$ & & & $32.1 \% 0^{5}$ & $44.7 \%^{9}$ & ND \\
\hline & $>2 \mathrm{cub}$ & 0 & & & $9.1 \% 6$ & $21.9 \%^{9}$ & ND \\
\hline \multicolumn{2}{|c|}{ Weight at birth } & $\pm 200 \mathrm{~g}$ & $261 g-450 \mathrm{~g})^{1,2}$ & ND & $330-440 \mathrm{~g}^{4}$ & $327 \mathrm{~g}^{9}$ & $350 \mathrm{~g}-465 \mathrm{~g}^{2,12}$ \\
\hline \multicolumn{2}{|c|}{ Interbirth-interval } & 0 & 142 days $^{1}$ & ND & 385 days $^{4}$ & 130 days $^{7}$ & $91-112$ days $^{2,12}$ \\
\hline
\end{tabular}

*Recent study in captivity in Research Centre for Biology-Indonesian Insititute of Sciences

after birth is approximately $232,9 \mathrm{~g}$ with the length of body, tail, head, and ear $(15 \mathrm{~cm}, 5 \mathrm{~cm}, 6 \mathrm{~cm}, 1 \mathrm{~cm}$, respectively). The hindfeet length about $5,5 \mathrm{~cm}$ and the front feet around $6 \mathrm{~cm}$.

In mammals, most of the studies on parent-offspring bonds have been based on mother-cub relationships, ignore paternal behaviour [52]. Male parental care appears to be critical for the survival of pups in several monogamous rodent species, for instance, Peromyscus californicus [53], Mus spicilegus [54], Microtus ochrogaster [64], and in Hystrix hodgsoni as well [11]. Sever and Mendelssohn [55], observed seven male captive $H$. indica spending $30 \%$ of the time alone with the newborns and $20 \%$ with both the female and their offspring.

In contrast, our study showed that females spent more time with newborn compared to male. Female spending $50 \%$ of the time with a newborn and the male spends 30\% with their cub. Indicated that biparental care intensively occurred also in Sunda porcupines. However, females are more dominant in maternal care as long as they do not enter the weaning period. The courtship behaviour was minimum occurred during the first two or three months of life of the offspring. The females mostly refuse to mate during the nursing period.

\section{Conclusion}

Tomato and bean sprout combination feeding increased birth rate, with twin litters per year. The reproductive peak of Sunda porcupine occurs between April to August. In captivity with food constant, the litters of Sunda porcupine is no more than two litter per year. The body weight of the offspring around $200 \mathrm{~g}$ after birth.

The authors thank Umar Sofyani and Ajay Supena for his invaluable help in the captive facility

\section{References}

1. D.J. Van Weers. Beaufortia 29 (356), 215-272 (1979)

2. R.M. Nowak, E. Walker. Walker's Mammals of the World, volume 1 (John Hopkins University Press, US, 1999)

3. K. Aplin. Hystrix javanica. The IUCN Red List of Threatened Species 2016:e.T10752A22231749. https://dx.doi.org/10.2305/IUCN.UK.20162.RLTS.T10752A22231749.en. Downloaded on 05 March 2020

4. R.J. Hall, E.J. Milner-Gulland, F. Courchamp Conserv. Lett. 1(2), 75-81 (2008)

DOI: 10.1111/j.1755-263X.2008.00013.x

5. P.A. Anadu, P.O. Elamah, J.F Oates. Hum. Ecol 16(2), 199-208 (1988)

https://doi.org/10.1007/BF00888092

6. T. Ebenhard. Trends Ecol. Evol. 10(11), 438-443 (1995)

DOI: $10.1016 / \mathrm{s} 0169-5347(00) 89176-4$

7. D. Shepherdson. The role of environmental enrichment in the captive breeding and reintroduction of endangered species. In Creative Conservation (pp. 167-177). (Springer, Dordrecht, 1994)

8. M. Dehnhard, S. Naidenko, A. Frank, B. Braun, F. Göritz, K. Jewgenow, K. Reprod. Domest. Anim. 43, 74-82 (2008)

9. A. Wallage, L. Clarke, L. Thomas, M. Pyne, L. Beard, A. Ferguson, S. Johnston Aust, J. Zool. 63(3), 181-191 (2015) https://doi.org/10.1071/ZO14069

10. Z.Z Zainal. The Journal of Wildlife and Parks, 16, 145-148 (1998) 
11. L.M. Gosling. J. Zool. 192(4), 546-549 (1980) https://doi.org/10.1111/j.14697998.1980.tb04250.x

12. W.R. Farida, R. Ridwan. Jurnal Biologi Indonesia 7(1) (2017)

13. G. Amori, L. Contoli, A. Nappi, A. Mammalia II: erinaceomorpha, soricomorpha, lagomorpha, rodentia. Vol. XLIV (Fauna d'Italia. Edizioni Calderini de Il Sole-24 Ore, Milano 736, 2008)

14. R. Nowak. Old World porcupines (Walker's Mammals of the World, 2, 1644-1689, 1964)

15. S. Agrawal. Antiseptic 115(3), 6-10 (2018)

https://pdfs.semanticscholar.org/af25/ed43a59694f 7124bae4d0b1de19343fc26cd.pdf

16. P. Tamilselvan, K. Langeswaran, R. Revathy, B.L Kumar, M.P. J. Biomed. Sci. 1(1), 41-47 (2014)

17. M.V. Raj, K. Selvakumar, G. Krishnamoorthy, S. Revathy, P. Elumalai, J. Arunakaran. Reproductive Sciences 21(1), 89-101 (2014)

18. S.E. Mulyani, M. Adriani, B. Wirjatmadi Int. J. Res 2(3), 15 (2016)

19. W. Fatmaningrum, W. S Ningtyas. Mung bean sprout extract suppresses Monosodium Glutamate (MSG) effect on the reproductive hormones (FSH and Estrogen) in female Wistar rats. (Majalah Obstetri \& Ginekologi, 27(1), 24-27, 2019)

20. M.R. Yeomans, J.E. Blundell, M. Leshem. Br. J. Nutr. 92(S1), S3-S14 (2004)

https://doi.org/10.1079/bjn20041134

21. M.P.S. Bakshi, M. Wadhwa, H.P. Makkar. CAB Reviews 11(012), 1-26 (2016)

DOI : $10.1079 /$ PAVSNNR201611012

22. F. Koch, J.U Ganzhorn, J.M Rothman, C.A Chapman, C. Fichtel. Am. J. Primatol. 79(4), 1-10 (2017)

DOI: 10.1002/ajp.22595

23. Y. R Bindari, S. Shrestha, N. Shrestha, T.N. Gaire. Adv. Appl. Sci. Res. 4(1), 421-429 (2013)

24. F. Ibtisham, A.A.M.I.R Nawab, G. Li, M. Xiao, L. An, G. Naseer. Med. Weter 74(6), 356-361 (2018)

25. C.M. Herring, F.W. Bazer, G.A Johnson, G. Wu. Exp Biol Med 243(6), 525-533 (2018)

DOI: $10.1177 / 1535370218758275$

26. G. Wu, F.W Bazer, T.A. Cudd, C.J. Meininger, T.E. Spencer. Nutr. J 134(9), 2169-2172 (2004) https://doi.org/10.1093/jn/134.9.2169

27. R.E. Fisher, M. Steele, N.A. Karrow. J. Pregnancy 2012 (2012)

DOI: $10.1155 / 2012 / 792934$

28. A.W.H. Braden, K.E. Turnbull, P.E. Mattner, G.R. Moule. Aust. J. Biol. Sci 27(1), 67-74 (1974) https://doi.org/10.1071/BI9740067

29. B. Kemp, L.A Den Hartog. Anim. Reprod. Sci 20(2), 103-115. (1989)

https://doi.org/10.1016/0378-4320(89)90068-7
30. W. R. Butler. J DAIRY SCI 81(9), 2533-2539 (1998)

31. Q. Johnson, W. Veith. Arch. Androl 46(2), 145-151 (2001) https://doi.org/10.1080/01485010151094092

32. M. Yildiz, M. Sandikci. Rom J Morphol Embryol, 57(2 Suppl), 703-713 (2016).

33. M. Adewoyin, M. Ibrahim, R. Roszaman, M.L. Isa, N.A.M. Alewi, A.A.A Rafa, M.N. Anuar, M. N. N. Diseases 5(1), 9 (2017) https://www.ncbi.nlm.nih.gov/pubmed/28933362

34. A. Zini, M. San Gabriel, J. Libman. Fertil Steril 94(3), 1033-1036 (2010) https://doi.org/10.1016/j.fertnstert.2009.04.004

35. A. Ates, s,ahin, G. Türk, I. Karahan, S. Yilmaz, A.O Çeribas, Ö. Bulmus. Fertil Steril 85 (2006) https://doi.org/10.1016/j.fertnstert.2005.11.035

36. M.F Ismail, H.M Mohamed. Cell Biochem Biophys 65(3), 425-432 (2013)

DOI: $10.1007 / \mathrm{s} 12013-012-9446-y$

37. M.G Mangiagalli, S.P Marelli, L.G Cavalchinl. Arch Geflugelkd 71(1), 25-29 (2007)

38. M.G Mangiagalli, P.A Martino, T. Smajlovic, L. Guidobono Cavalchini, S.P Marelli. Br. Poult. Sci 51(1), 152-157 (2010)

DOI: $10.1080 / 00071660903401540$

39. D. Durairajanayagam, A. Agarwal, C. Ong, P. Prashast. Asian J Androl 16(3), 420 (2014)

DOI: $10.4103 / 1008-682 X .126384$

40. H. Watanabe, S. Okawara, M.M.U Bhuiyan, Y. Fukui. Reprod Domest Anim 45(5), 838-845 (2010) https://doi.org/10.1111/j.1439-0531.2009.01365.x

41. E. Hidayat, R. Susanti, A. Marianti. J. Pharm 26(4), 192 (2016)

42. D. Winarso, B. Purwo. Y.R Kusuma J. Cell Anim. Biol. 5(13), 283-289 (2011)

43. S.M. Boué, T.E. Wiese, S. Nehls, M.E Burow, S. Elliott, C.H Carter-Wientjes, T.E. Cleveland, T. E. J Agr Food Chem 51(8), 2193-2199 (2003) DOI: $10.1021 / \mathrm{jf0} 21114 \mathrm{~s}$

44. K. F. M. Reed. Agriculture 6(3), 35 (2016) https://doi.org/10.3390/agriculture6030035

45. W. Fatmaningrum, W. S Ningtyas. Mung bean sprout extract suppresses Monosodium Glutamate (MSG) effect on the reproductive hormones (FSH and Estrogen) in female Wistar rats. (Majalah Obstetri \& Ginekologi, 27(1), 24-27, 2019)

46. W. Rohmawati. Pengaruh Kombinasi Vitamin $C$ Dan E Terhadap Kadar Follicle Stimulating Hormone (FSH) Dan Malondialdehid (MDA) Pada Tikus Yang Dipapar Monosodium Glutamate (MSG) (Doctoral dissertation, Universitas Brawijaya, 2014) 
47. Z. Madar, A.H Stark. Br. J. Nutr 88(S3), 287-292 (2002)

DOI: https://doi.org/10.1079/BJN2002719

48. M. Sönmez, T. Bozkurt, G. Türk, S. Gür, M. Kızıl, A. Yüce. Anim. Reprod. Sci 114(1-3), 183-192 (2009)

49. J. D. Skinner, R.J. Van Aarde, A.S. Van Jaarsveld. S. Afr 19(2), 82-86 (1984) https://doi.org/10.1080/02541858.1984.11447862

50. R.J. Van Aarde, J.D. Reproduction 76(2), 545-552 (1986) https://dx.doi.org/10.1530/jrf.0.0750577

51. R.J. Van Aarde, V. Van Wyk. Reproduction 92(1), 13-19 (1991) https://doi.org/10.1530/jrf.0.0920013

52. Gubernick, Alberts. J Comp Psychol 101(2) (1987)

53. Gubernick, Teferi. Proc Biol Sci. 267(1439): 147150 (2000)

54. B. Patris, C. Boudion. Behav. Processes 51,35-43 (2000)

55. Sever, Mendelssohn. Isr. J. Zool 36 (1989)

56. M.F Ismail, H.M Mohamed. Cell Biochem Biophys 65(3), 425-432 (2013)

57. A. Ahmad, I.M Chaudhry. Pakist J. Forest 27(3) (1977)

58. E.L Barthelmess. Mammalian Species 788, 1-7 (2006)

https://www.researchgate.net/publication/23269230 8 Hystrix africaeaustralis

59. C. Bartos. Husbandry Standards for Keeping Porcupines in Captivity (Baltimore Zoo. Druid Hill Park. Baltimore. MD, 21217, 2004)

60. G.R. Beecher. Proc. Soc. Exp. Biol. Med 218(2), 98-100 (1998)

https://doi.org/10.3181/00379727-218-44282a

61. P.K Dahiya, M.J.R. Nout, M.A. van Boekel, N. Khetarpaul, R.B. Grewal, A. Linnemann. Brit Food J 116(6) (2014)

DOI: $10.1080 / 10408398.2012 .671202$

62. M. Dehnhard, S. Naidenko, A. Frank, B. Braun, F. Göritz, K. Jewgenow. Reprod Domest Anim 43, 74-82 (2008) DOI: $10.1111 / \mathrm{j} .1439-0531.2008 .01145 . \mathrm{x}$

63. D. Erba, M.C. Casiraghi, A. Ribas-Agustí, R. Cáceres, O. Marfà, M. Castellari. J Food Compost Anal 31(2), 245-251 (2013)

64. J. O. Wolff, P.W. Sherman. Rodent societies: An ecological and evolutionary perspective. (Chicago, IL: University of Chicago Press, 2008)

65. A.M Kylen, R.M Mc Cready. J. Food Sci 40(5), 1008-1009(1975)

DOI: 10.1111/j.1365-2621.1975.tb02254.x

66. A. Kavas, S.N El Nutritive. J Consum Stud Home Econ 15(4), 357-366 (1991) https://doi.org/10.1111/j.1470-

6431.1991.tb00675.x

67. A. Raiola, M.M. Rigano, R. Calafiore, L. Frusciante, A. Barone.Mediators Inflamm, (2014) https://doi.org/10.1155/2014/139873

68. W.W Ifafah, S. Rahayu, D. Diapari, M. Baihaqi, M. The utilization of bean sprout waste as a sheep feed in order to reduce waste pollution in traditional Indonesian market. (In Proceedings of the 18th TriUniversity International Joint Seminar and Symposium (pp. 26-31), 2011, October)

69. E. Mohr. In: A. Ziemsen Verlag, AWissenschaften, Westarp (Eds.), A. Altweltliche Stachelschweine. A. In E. Mori, M. Menchetti, M. Lucherini, A. Sforzi, S. Lovari. MAMM BIOL 81(4), 345-349 (2016)

70. R.J. Van Aarde. Reproduction 75(2), 577-582 (1985) https://doi.org/10.1530/jrf.0.0750577

71. I.G. Gaigher, M.H Currie. Preliminary studies on the ecology of the southern African porcupine, Hystrix africaeaustralis.(Department of Nature and Environmental Conservation, Province Administration of the Cape of Good Hope, South Africa, 55-69, 1979) https://doi.org/10.1080/11250008709355592

72. A. Khaliq, R.A. Khan, S. Yaqoob, A. Majeed, Pak. J. Agric. Sci 12 (1991)

73. E. Mori, M. Menchetti, M. Lucherini, A. Sforzi, S. Lovari. Mamm Biol 81(4), 345-349 (2016)

74. B. Weir. Symp. Zool. Soc. London 34, 265-301 (1974)

75. W.R Farida, A.P. Sari, N. Inayah, H.A Nugroho, H. Observations of behavioural development on common Porcupines (Hystrix brachyura) undergoing domestication. (In IOP Conference Series: Earth and Environmental Science Vol. 308, No. 1, p. 012076, IOP Publishing, 2019)

76. M. Farhangi, L.R.G Valadon. J. Food Sci 47(4), 1158-1163 (1982) https://doi.org/10.1111/j.13652621.1982.tb07640.x 